BREAKING

THE CYCLE:

\title{
EDUCATION AND
}

\section{THE FUTURE}

FOR AFGHAN

\section{REFUGEES}

SEPTEMBER 2015

NRC NORWEGIAN

REFUGEE COUNCIL

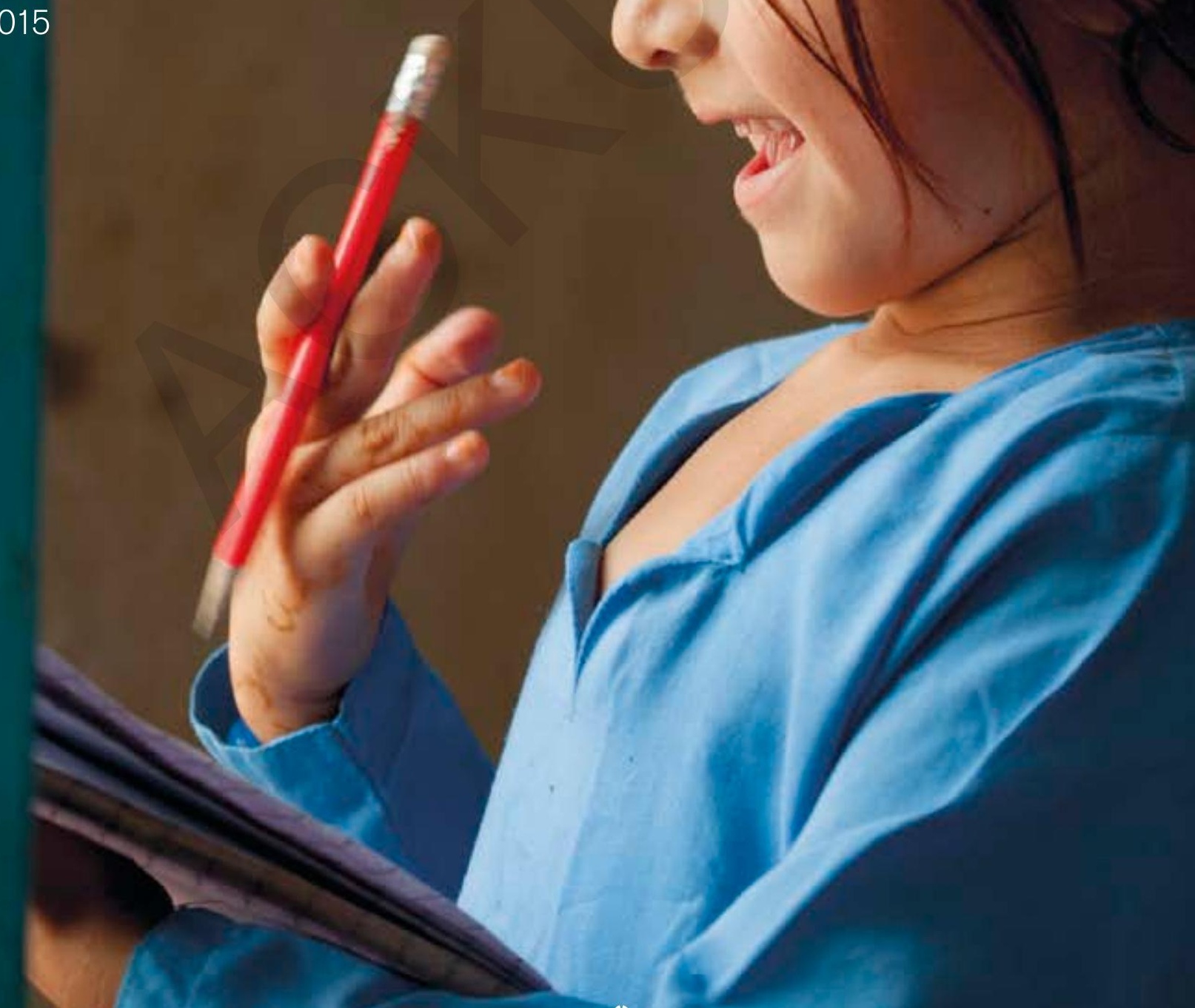

(M) UNHCR The UN Refugee Agency 


\section{FOREWORD}

This year's Nansen Refugee Award winner, Aqeela Asifi, is being honoured for her courageous work and significant contribution to refugee girls' education. Since arriving in Kot Chandana refugee village in Punjab, Pakistan, 23 years ago, Asifi has worked tirelessly to allow the girls of its deeply conservative and impoverished Afghan refugee community to access primary and secondary education. To date, her hard work, sensitivity to cultural and religious values, and persistence have resulted in one thousand girls having the opportunity to attend her school at both primary and secondary level, receiving national lower secondary certification. Two generations of graduates have passed through her school, going on to become teachers, pursue further education and support their families, in Pakistan as well as upon their return to Afghanistan.

The true value of Asifi's contribution to her community and girls' education as a whole is difficult to comprehend without understanding the extremely challenging context within which she has operated over the past 23 years. This report seeks to provide that context. Drawn from field interviews in Pakistan, as well as desk research, this report will look at the education landscape for Afghan refugees in Pakistan, with a special focus on girls. It will outline some of the challenges children face in accessing quality education and the dangers if quality education is not provided - for both boys and girls. It also aims to highlight the considerable benefits primary and secondary education can offer - for the individual, the community, the host country and the country of origin. Finally, this report will review some of the ongoing innovative efforts to deliver increased access to quality education for Afghan refugees in the South West Asia region.

Written by: Charlotte Jenner

Cover page photo: CUNHCR/Sebastian Rich 



\section{A challenging education context}

In the best of circumstances, educating more than a million school age refugees would be a major challenge. Pakistan and Iran face innumerable obstacles educating their own populations, yet both countries generously allow refugee children to attend their schools. Despite this, enrollment of Afghan children in education remains low.

In Pakistan, some 80 per cent of the school age Afghan refugee population is currently out of school (4), resulting in extremely low literacy among Afghan refugees. Only an estimated 33 per cent of Afghan refugees in Pakistan are able to read and write. Literacy among women and girl refugees is even lower at approximately 7.6 per cent (5).

Access to education for Afghan refugees in Pakistan sits within an extremely challenging national education context. Pakistan has the second largest number of out-of-school children in the world, with an estimated 25 million Pakistani children out-of-school. (6). Some 62 per cent of those children are girls. As a result of these low levels of access to education, 45 per cent of the adult Pakistani population is illiterate and less than half of the female population over the age of 15 in Pakistan are able to read and write (7).

In Iran, 98 per cent of the Iranian population aged 15 - 24 is literate and 94 per cent of the population complete primary school (8). Afghan refugees have the right to access Iranian public schools, although fees can be restrictive for some Afghan families. That said, in the 2013 -2014 school year, 338,276 refugee children, Afghan and Iraqi, accessed education in Iran, a seven per cent increase on the previous year.
In Afghanistan, the education landscape has improved significantly since the fall of the Taliban in 2001. Enrolment rates in Afghan schools have risen, with girls' enrolment in primary rising from less than 40 per cent to over 80 per cent and secondary rising from 5 per cent to over 34 per cent. In just five years, literacy among women and girls aged 15 to 24 has also increased to 30 per cent nationwide and to almost 40 per cent among young urban women in Afghanistan. Whilst these figures are still low, relatively speaking, they show a promising improvement in just five short years (9). However barriers remain, particularly for returnees including poverty, socio-cultural restrictions upon girls, poor infrastructure and lack of qualified teaching staff, particularly female teachers. In provinces plagued by conflict and instability, as few as one per cent of teachers are female. In Afghanistan an estimated 3.5 million children are still out of school (10).

Because of the protracted nature of the Afghan displacement, where the education of first generation refugees had been cut short by displacement or was non-existent, second and third generations encounter barriers due to poverty, strict socio-cultural traditions or other institutional reasons. This self-perpetuating cycle particularly affects girls. Low numbers of girl graduates leads to steadily decreasing numbers of female teachers for higher grades, further limiting access to primary and secondary education for future generations.

This not only impacts the Afghan refugee community in Pakistan but has far reaching implications in Afghanistan too, restricting opportunities for sustainable return, stifling the vast potential of Afghan refugee youth and limiting national progress in education and development. 


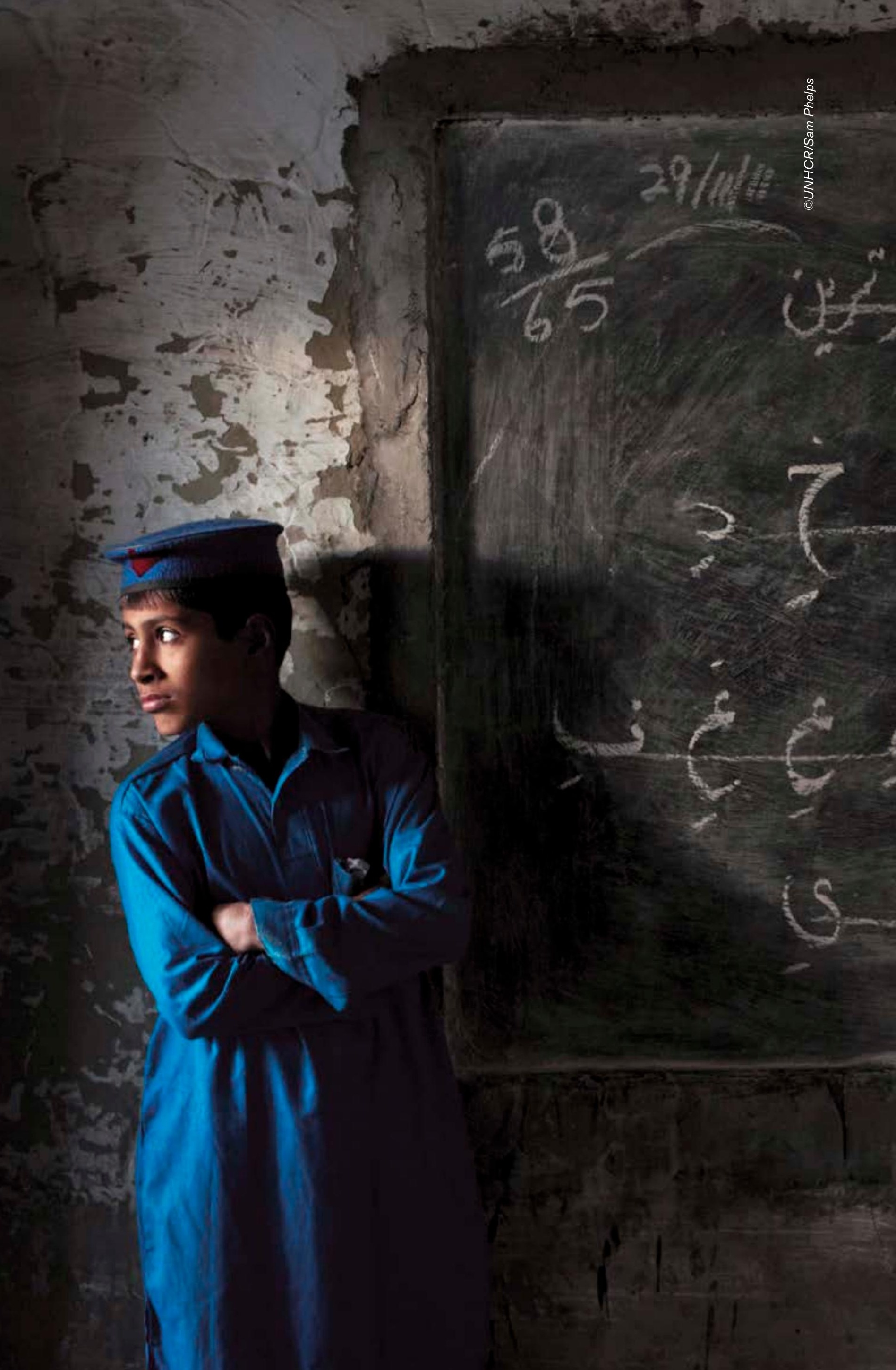




\section{Powerful potential}

When Afghan refugee children are given the opportunity to access primary and secondary education, whether through public schools in their host countries or through communitybased mechanisms, the positive results are self-perpetuating - not only improving the lives of individual Afghan students but those of their families, wider community and future generations. Children and youth who access education and training are better equipped to contribute to their host communities during displacement and play their part in the development of their country of origin - as teachers, doctors, engineers or other members of the Afghan workforce. Educated girls go on to become educated mothers, who are able to support their children's schooling, contribute financially, and address their own and their families' health and wellbeing.

The tireless work of educators and community activists, such as this year's Nansen Refugee Award winner, is testament to the fact that solutions can be found, even in the most challenging of contexts. So too, efforts to provide education options for Afghan refugees, by host governments, NGOs, UN agencies, public schools and civil society have unequivocally proven the benefits of education and training, particularly for Afghan refugee girls.

The key challenge is to ensure that all Afghan refugee girls and boys are able to consistently access primary and secondary education and training. Whilst there is still room for progress, there have been a range of innovative solutions.

\section{- Community and home-based interventions for girls}

Community and home-based schools are proving successful options for girls who would otherwise not have the opportunity to learn, as a result of geographic, economic or sociocultural restrictions. Communitybased education interventions, such as the girls' school set up and run by Aqeela Asifi, are affecting lasting change within remote and conservative communities. In so doing, they are opening up long-term opportunities for Afghan children and youth.

\section{- Capacity-building for public schools to increase access for refugees}

The benefits for Afghan refugees of accessing full primary and secondary education within the public system in their host country are huge - in terms of learning outcomes, inclusion, protection, opportunities for future study and prospects for voluntary repatriation. This goes hand in hand with UNHCR's overall global policy to support existing systems to absorb refugee learners. However, the public school systems in host communities, particularly in Pakistan, are in many cases already overstretched. Under the umbrella of the regional Solutions Strategy for Afghan Refugees (SSAR) - see box on page 19 - interventions, such as the Refugee Affected and Hosting Areas (RAHA) project, have allowed UNHCR to focus its efforts upon building the capacity of the public school system, to support the inclusion of Afghan students. To help build capacity under the RAHA scheme, UNHCR has funded refurbishment and construction of classrooms, as well as the creation of gender-specific facilities in girls' schools to encourage increased enrolment.

\section{- Skills training for refugees}

Skills and vocational training is a key solution to allow Afghan refugees the opportunity to sustainably support themselves and their families, within their host communities, as well as upon return to Afghanistan. Training in vocational skills, from tailoring to masonry, plumbing and computers, has proven extremely effective, particularly for women and girls. Training provides better earning opportunities, increases women and girls' mobility, and empowers female refugees within their homes and their communities.

While the education landscape for Afghan refugees may be challenging, creative solutions are emerging, driven by the inspiring work of members of the Afghan refugee community like Aqeela Asifi. Asifi's story captures the hope that education brings for a brighter, more sustainable future for Afghans, both in exile and upon return to Afghanistan. Her story is an inspiring example of how many Afghan refugees are taking their community's struggle into their own hands, using education to break the cycle of poverty and isolation and create a new generation of empowered and educated children. By educating girls, Asifi has gone further still, ensuring the impact of her work spreads far beyond her own community and single generations - lighting the fire of education in generations of girls to come.
"Education is light. Without it we are in the dark forever. We are blind" 


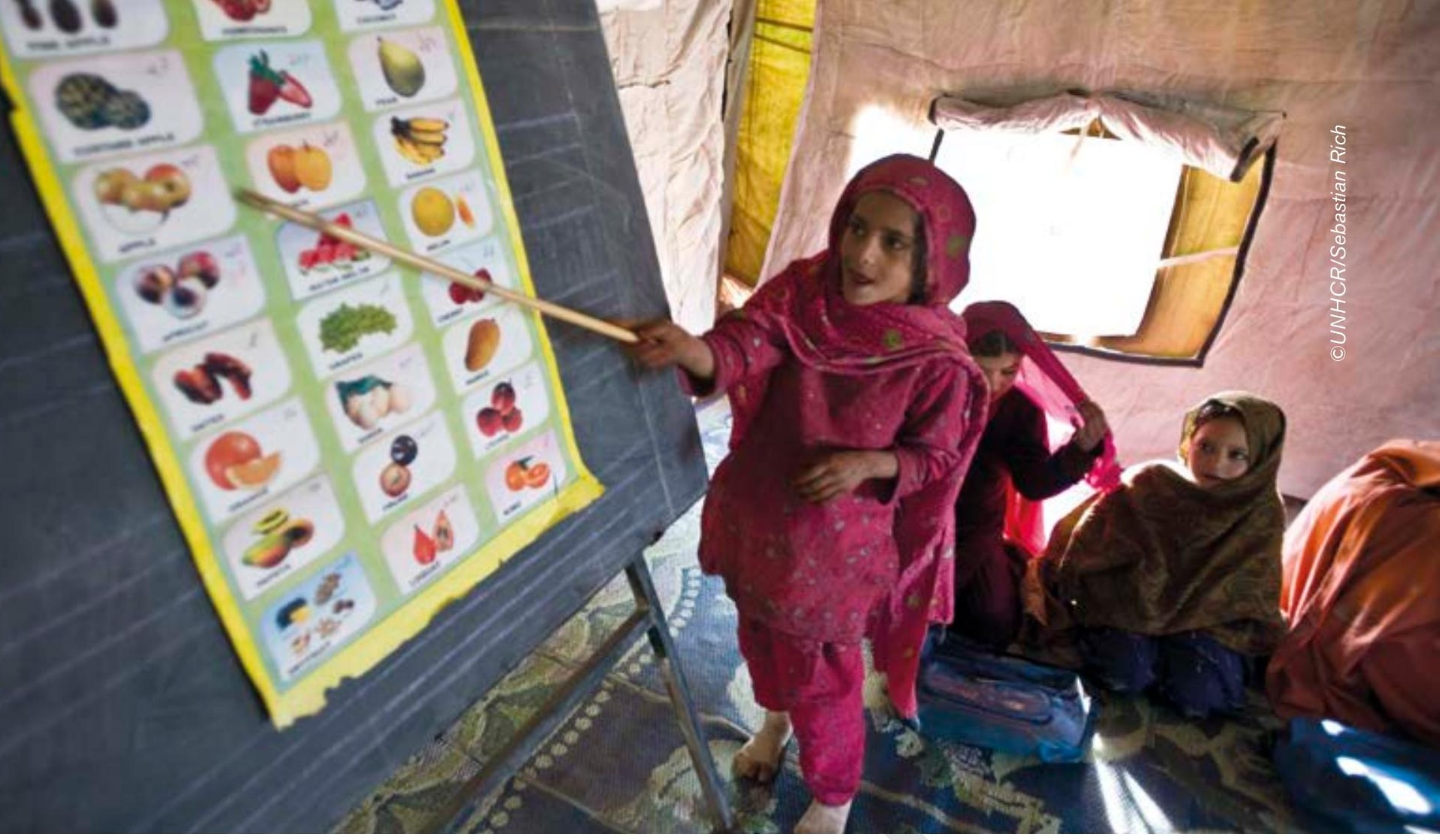

\section{ACCESS TO PRIMARY AND SECONDARY EDUCATION FOR AFGHANS IN PAKISTAN}

As a community that has experienced displacement for over three decades, Afghan refugees in Pakistan view education as a pathway to a better future, as well as a fundamental part of rebuilding their home nation. Different education options are currently available to Afghan refugees in Pakistan, with varied levels of access between refugee village, rural, semi-urban and urban settings.

\section{Refugee village schools}

Across 54 refugee villages ${ }^{3}, 127$ local NGO and UNHCR supported schools provide primary education to Afghan refugees, reaching 59,000 children. With limited funding, refugee village schools struggle to acquire and retain qualified teachers, which impacts upon the quality of education. Dropout rates in these schools are high, at around 70 per cent. Girls demonstrate a particularly worrying dropout rate, of 90 per cent. The reasons for leaving are often connected to poverty-induced child labour and sociocultural expectations that girls should remain at home. Limited numbers of students from these schools progress to secondary level, either due to sociocultural restrictions, financial constraints, differences in curriculum, certification issues or the proximity of public schools. Despite the limitations, refugee village schools have been the sole provider of primary level education for thousands of the most vulnerable Afghan refugees over the past 30 years.
'When Afghan students get to study while they are here in Pakistan you can see that they have so much potential. Despite any initial language barriers or the poor quality education they may have had before, Afghan students tend to get very high results. The talent is there. The potential is there. These children just need the chance and they will succeed.'

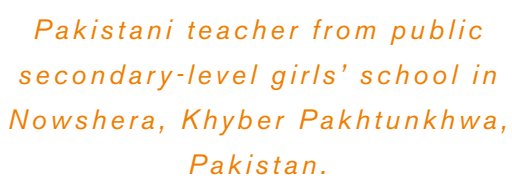

Pakistan. 

Hinges.

9.196.

if

y.

forsting

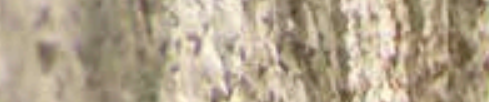

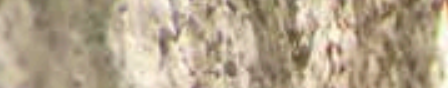

singtion

ir existis

s.7. Pind

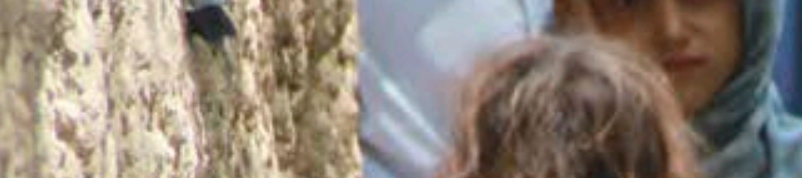

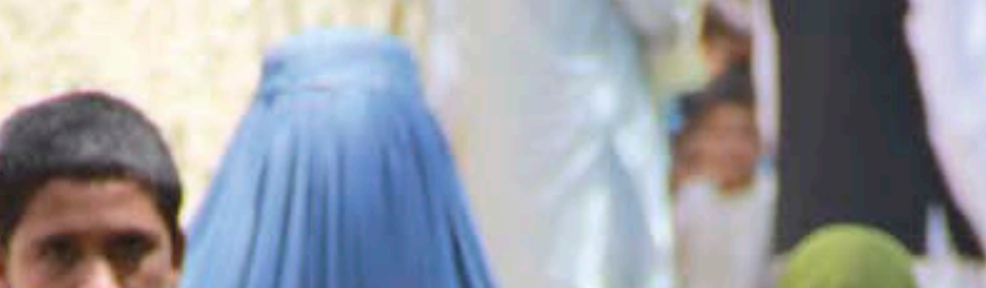

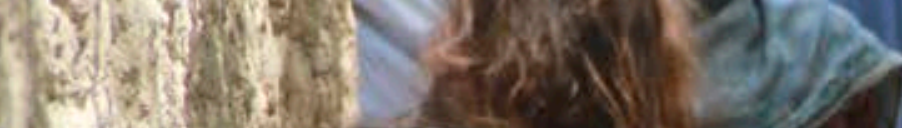

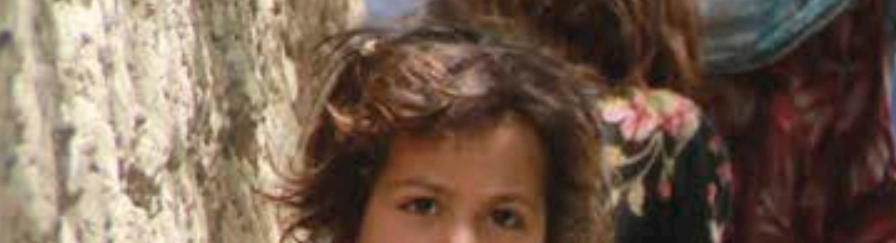

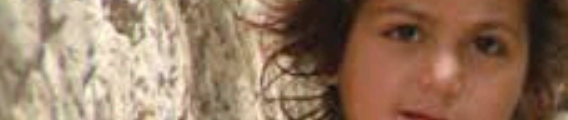

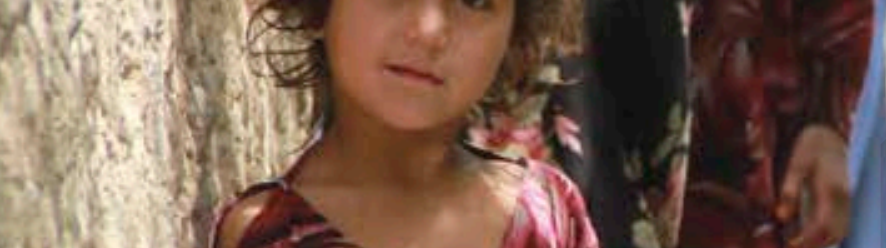
Ningen

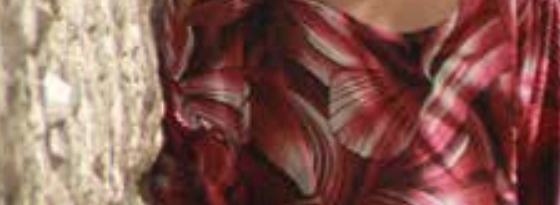

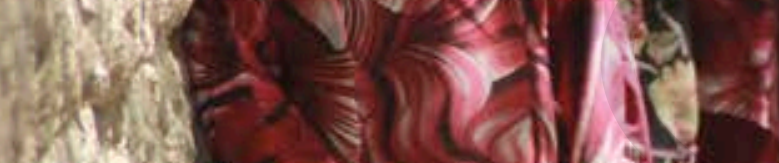

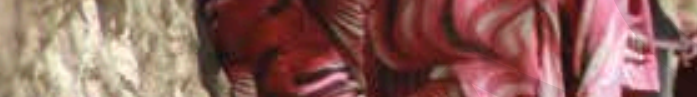

W(1)

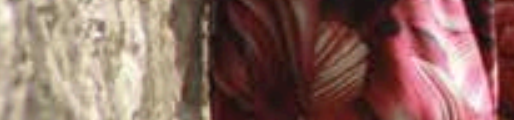

sire $)^{3}$

beas

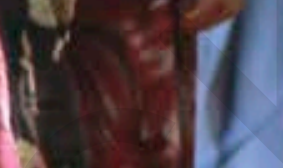

i

s

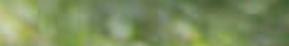

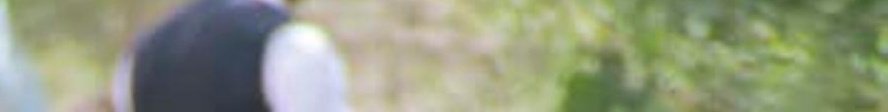




\title{
4. BARRIERS TO EDUCATION FOR AFGHAN REFUGEE WOMEN AND GIRLS, AND THE RISKS OF LIMITED ACCESS
}

\author{
While education and training options are available to Afghan refugees in Pakistan, Afghan refugee \\ women and girls face substantial challenges in terms of access, particularly to secondary level \\ schooling. Sociocultural restrictions on mobility and rights, institutional barriers related to facilities \\ and culturally appropriate environments, as well as poverty, all limit girls' access to primary, secondary \\ and tertiary education, during displacement and upon return to Afghanistan.
}

\section{Sociocultural barriers}

While many Afghan refugee families speak convincingly of the benefits of education for their sons, they often do not see the same benefit in sending their girl children to school. Entrenched gender roles within often very conservative Afghan refugee communities have created an environment where girls are expected to remain at home to carry out domestic and child rearing responsibilities.

Child marriage and teenage pregnancy are often cited as major barriers to the continuation of education for Afghan refugee girls, particularly to secondary level. Many girls are taken out of school to be married, as early as grade six. This often leads to girls falling pregnant, at which point their hopes for continuing their studies slip further out of reach. Most girls who become pregnant do not return to school (13).

Girls often face further exclusion at the secondary level as few schools exist. Travelling to government schools poses a problem for many. Since Afghan refugee girls are often forbidden to leave home without a male family member, they lack mobility and literally can't get to a school. This, coupled with parental concerns over girls' safety on the way to or within the school environment, also presents significant barriers to accessing education.

\section{Institutional barriers}

Sociocultural obstacles are further compounded by the shortage of female teachers within the Afghan community as well as in Pakistani public schools, particularly at higher grade levels. Unable to be taught by male teachers once they become adolescents, girl students who want to further their education often face a major roadblock. With so few girls accessing secondary and tertiary education, this shortage of female teachers has become critical, creating a widespread blockage to girls' accessing education. The lack of trained female teachers has a knock-on effect for those returning to Afghanistan, as there are too few qualified female returnees to teach Afghan girl students.
'Even if parents start to come round to the idea of educating their daughters, the lack of female teachers means they will never say yes, because the girls cannot be taught by male teachers. It is a vicious cycle.'

Wisaludin, 21, youth and education activist in Akora refugee village in Nowshera, Khyber Pakhtunkhwa

Additionally, the lack of gender-friendly schools for girls creates further barriers. Inadequate or non-existent bath-rooms, absence of drinking water and the need for perimeter walls or viable transport options, make parents hesitant or unwilling to send their daughters to school.

\section{Economic barriers}

For many Afghan refugee families, education is economically out of reach. The price of uniforms, materials, books, and transport to and from school are simply too costly. Whilst poverty restricts some Afghan refugee girls from entering education at primary level, the impact is most profound at secondary level, when related expenses increase. Struggling under the weight of extreme poverty and influenced by the deeply entrenched gender roles, some families will choose to spend what money they have to educate their boys instead of the girls.

'My daughter has reached Grade 10 but we cannot afford to send her on to college. The cost is just too high. My husband is a daily wager and I have no education or skills so I cannot work. We live hand to mouth. Now she sits at home with me and it breaks our hearts.' 


\section{CONSEQUENCES WHEN GIRLS LACK ACCESS TO EDUCATION}

\section{Reinforcing harmful traditions and gender norms}

When girls are unable to go to school, this often serves to reinforce the negative gender roles and cultural norms that restricted their access in the first place. This can leave them more vulnerable to child marriage, marriage without consent, teenage pregnancy and gender-based violence. Girls who are not in school or any other form of training are denied access to protective environments, as well as the opportunity to acquire the skills to improve their lives. The resulting inability of girls to work or contribute financially to their families also serves to reinforce the view that they are a financial burden. Arranging marriages and dowries for girls is often seen as the only option for relieving that burden, with girls in some communities being promised for marriage as young as five years old and married off as early as 12 .

Uneducated women and girls are often in a relationship of dependency upon the male members of their family, which in many cases can leave them vulnerable to domestic violence and other rights abuses. Illiterate women and girls are often more isolated, confined to their homes and domestic chores, making them less able to seek help or support if they are the victims of violence. According to a World Bank report, the majority of women who have not achieved secondary education are married as children and lack control over their household resources, compared to five per cent of women who finish high school. (14)

II used to love going to school. The teachers were so inspiring to me, I wanted to be like them and I felt free. But when I turned 12 my father told me I had to stop. I was married and now I have a baby. When I think of school I smile. But now I am at home and school is just in my memories.'

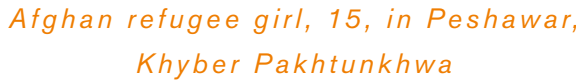

\section{Negative repercussions for health}

Extremely low levels of access to education and training for both Pakistani girls and Afghan refugee girls over the past 35 years has not only led to a shortage of female teachers but also a shortage of female doctors, particularly in rural areas. Cutting girls' education short thus not only impacts future generations' education opportunities and denies girls important role models, but also has a wider impact upon women's and girls' health. Without high quality, sustained education opportunities for girls, from primary through to tertiary, there are even fewer female doctors in the Afghan and Pakistani community than there are teachers. As a result, those in remote areas are left with limited access to much-needed medical care and attention, particularly during pregnancy.

Lack of education also leaves many Afghan women and girls without the basic skills to address the health and hygiene needs of themselves and their children. As a result, maternal mortality rates for women and girls who have not been educated are significantly higher than those who have been to school. Furthermore, according to research carried out by UNESCO, each year of a mother's schooling reduces the probability of infant mortality by five to ten per cent (15).

\begin{abstract}
'I want to educate my daughters so they can become doctors and teachers. We need them. For the future of Afghanistan and for us here, the women in our community need them. But we can't afford to send them and now they just sit at home.'
\end{abstract}

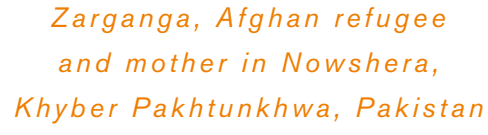

\section{Child labour}

Allowed only to work in the informal sector and unable to access education that could help them earn a living wage, generations of Afghan refugees have been mired in poverty. As a result, some refugee children are obliged to help support their families instead of getting an education. In other cases, those who have accessed school are forced to drop out in order to work, while others may be working to pay for their studies. It's estimated that children aged 5 to 14 make up around six per cent of the Afghan refugee work force in Pakistan, while youth aged 15 to 24 make up 31 per cent (16).

Whilst child labour is typically seen as an issue that affects boys, young Afghan refugee girls are also engaged in informal labour, from garbage collection to domestic work, carpet weaving and brick making. 


\section{BREAKING THE CYCLE - THE BENEFITS OF EDUCATION FOR GIRLS}

While it is Afghan refugee women and girls who must overcome the greatest obstacles, when they access school or training the impact is profound. Through education they are able to take control of their own futures, improve their health and wellbeing and contribute financially to their family. But the benefits do not end there. Educating Afghan refugee girls helps to ensure education for future generations and improved chances for sustainable voluntary repatriation in Afghanistan.

\section{The multiplier effect}

Primary and secondary education equips girls with new skills and confidence. What's more, the World Bank argues that educating girls and women creates a multiplier effect - educated women earn more, have fewer children, and provide better health care and education to their children (18). This year's Nansen Refugee Award winner, Aqeela Asifi's contribution to girls' education powerfully illustrates this point, as well as showing that education for refugee girls has an impact far beyond the young minds that are being educated. As a result of Asifi's work, more schools have opened in Kot Chandana refugee village, further broadening access to primary and secondary education for refugee children and youth; entrenched gender roles of women and girls have slowly begun to shift; and graduates of her school have taken their education back to Afghanistan, becoming teachers and even setting up similar girls schools in remote areas.

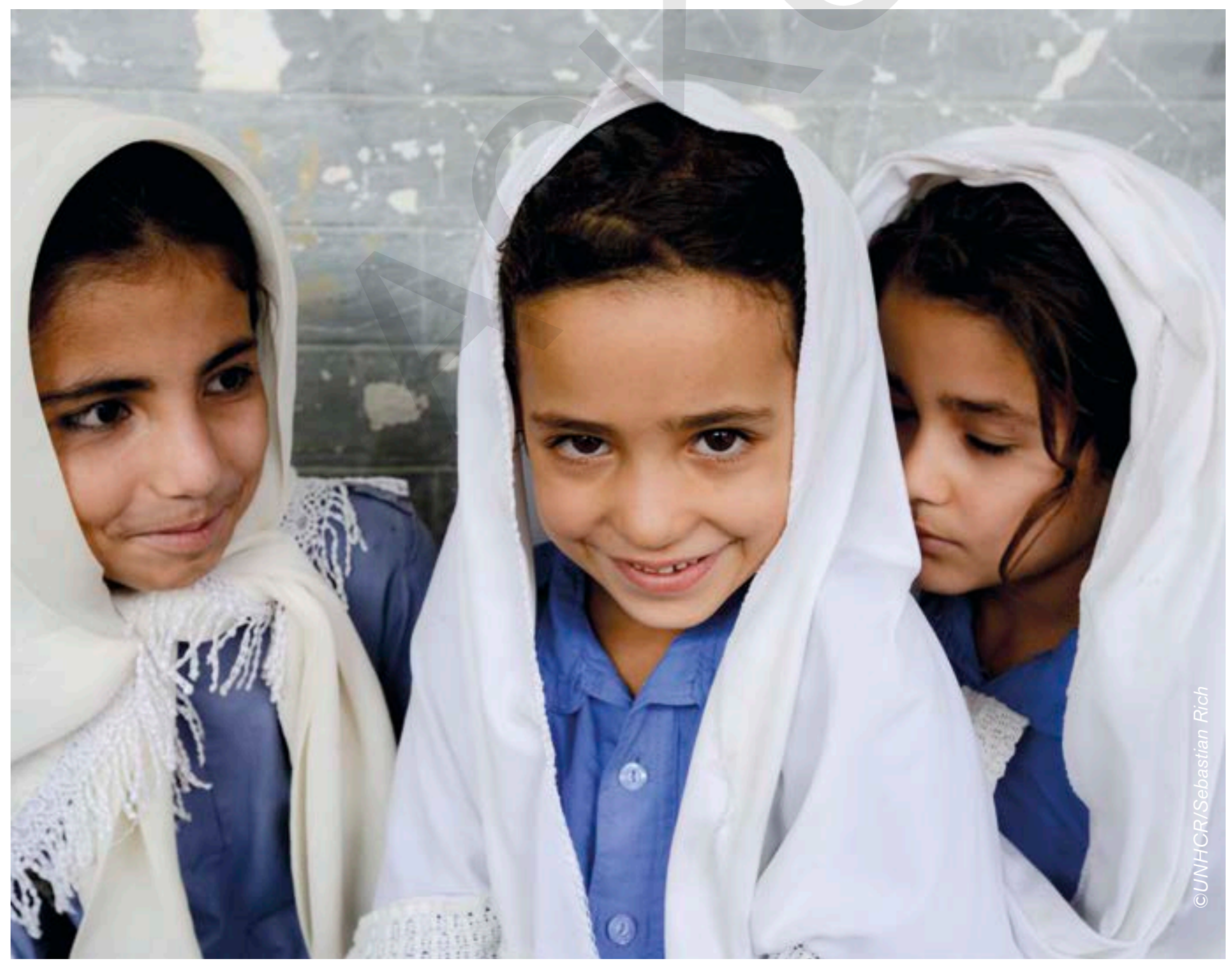





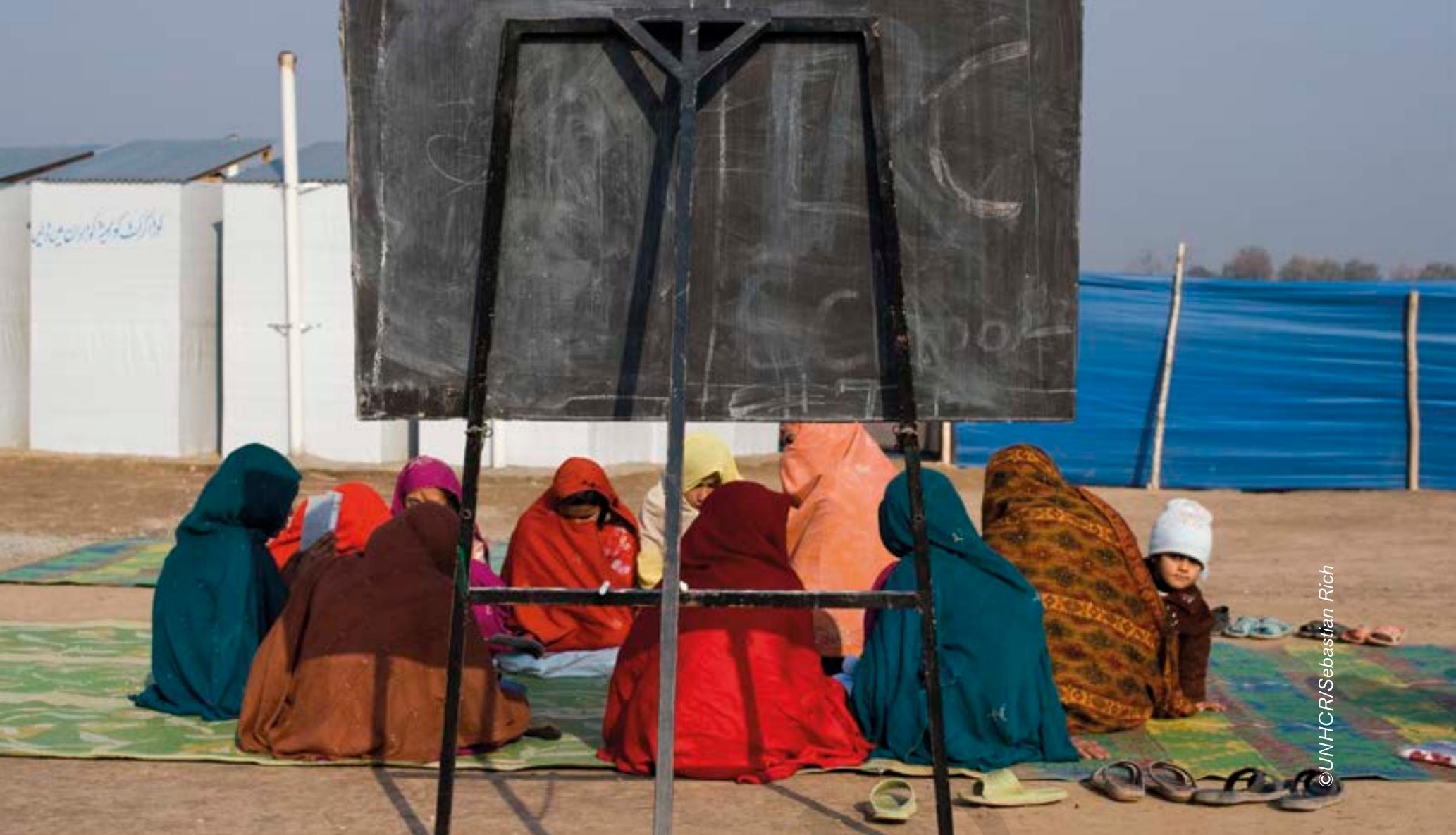

\section{Passing on the gift of education}

Educating girls creates the educated mothers of the future, which in turn leads to second generations of educated children. Evidence suggests that educated mothers are significantly more likely to send their own children to school, in addition to being more able to help them with their studies, helping to break the cycle of poverty and lack of access to education. According to UNICEF, children whose mothers have had no education are more than twice as likely to be out of school as those whose mothers are educated (20). Girls education thus plays a vital role in securing more positive and productive futures for Afghan children and youth, both while in exile and upon return.

'We have girls from 25 provinces across Afghanistan in our community school here. When they go back they can play a positive role in all those different provinces. They can teach others. Two graduates from our school here have returned to Afghanistan and are working in a government school in a Taliban stronghold. They have taken the model of what we did here in Kot Chandana back to Afghanistan to help girls access education there. That is what we wanted to achieve with this school from the beginning.'

\section{Supporting the family}

Educated refugee girls are also more able to help their families financially, in ways that avoid child labour. For the girls themselves, this is a hugely empowering step, especially in contexts where they would otherwise be confined to domestic work. For their families and communities, educated girls have a crucial role to play in identifying a way out of the cycle of poverty that constrains so many Afghan refugees. For example, students of Aqeela Asifi's community girls' school in Kot Chandana are using their education to help their fathers, brothers and uncles with their small businesses, organising accounts, helping to read bills and calculating payments.

Further still, girls' education and training not only helps individuals and communities to break the cycle of poverty by improving their livelihoods prospects, it also unleashes human capital, improving productivity and boosting economic growth, both in host countries and upon return to Afghanistan. Indeed, according to research by UNESCO, if all students in low-income countries, including girls, left school with basic reading skills, 171 million people could be lifted out of poverty, resulting in a 12 per cent cut in poverty worldwide (19).

\footnotetext{
Aqeela Asifi, 2015 Nansen Refugee

Award winner, teacher, founder and

headmistress of girls' community school

in Kot Chandana refugee village

in Pakistan.
} 


\section{LONG-TERM BENEFITS: RETURN, RECONCILIATION AND REBUILDING}

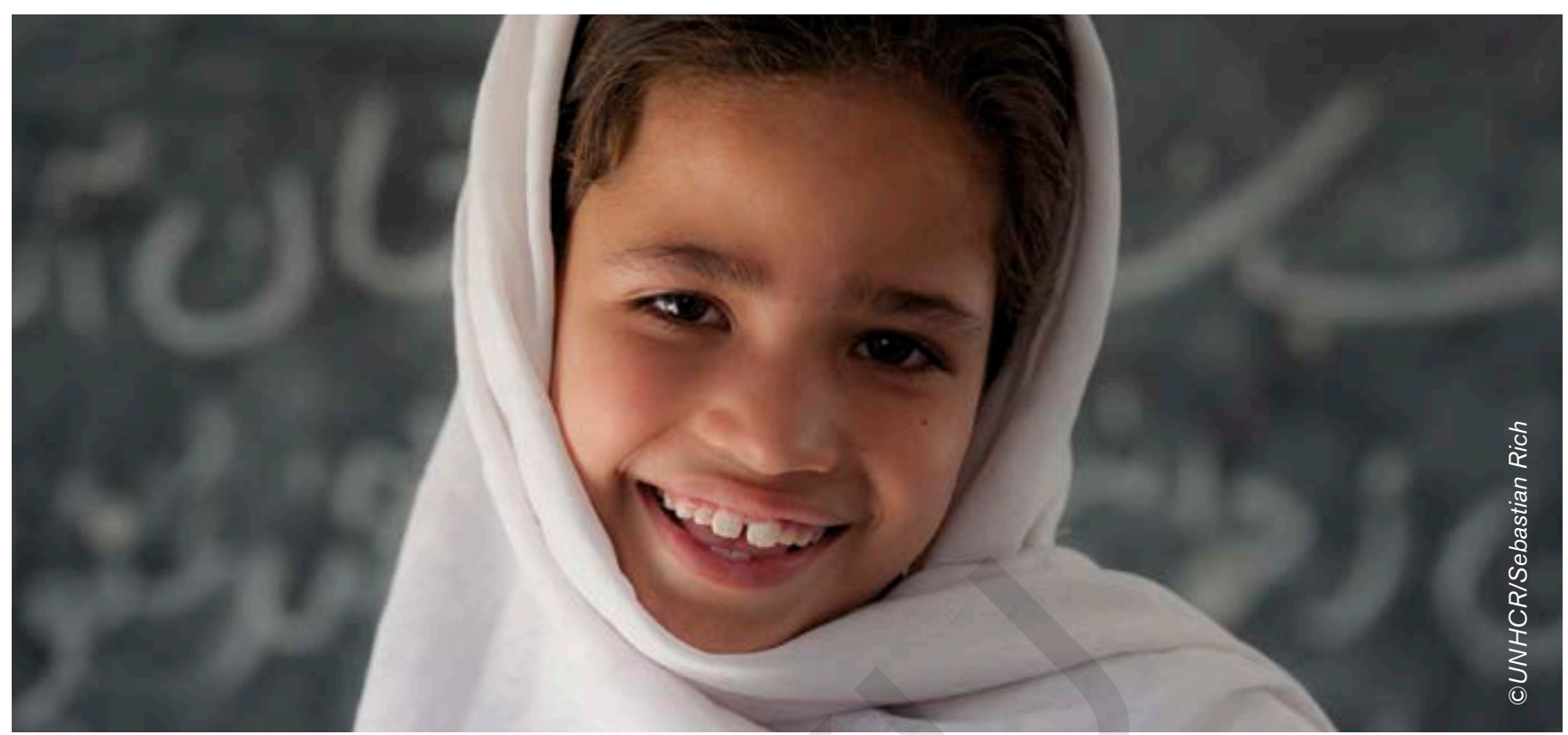

The Afghan refugee community identifies educated young people, who have had access to full primary and secondary education, as playing a lead role in the future of Afghanistan.

Being able to obtain a national certificate for education while in Pakistan that is accepted or receives equivalency in Afghanistan thus becomes the key with which educated Afghans are able to unlock their future - be it continuing their studies, progressing to vocational or technical training, or seeking employment.

\section{'Education is self-defence. Without education you are weak, you have no way of protecting yourself. With education you can fight those who would exploit your ignorance. Knowledge and information are your weapons. You can find your own way and you can see what is right.'

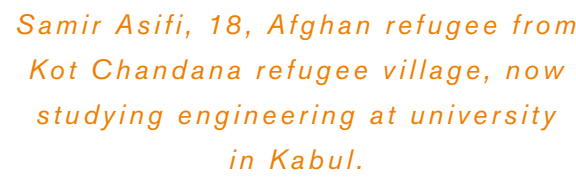

Those refugee students who complete secondary education in Pakistan and receive recognised certification in many cases seek to continue to higher education in Afghanistan. Once graduated, these students often go on to look for jobs in Afghanistan, in a range of sectors, including teaching, medicine, engineering, development, the civil service, IT and business.

As a result of their accessing primary and secondary education in their host country, these young people are more likely to be able to realise opportunities for sustainable return in Afghanistan. Indeed, research shows that educated Afghan refugees are three times more likely to successfully repatriate (16).

The role schools play in bringing communities together is also vital. In the overwhelming majority of cases, the inclusion of Afghan refugees in public school systems of host countries creates positive relationships, allowing Afghan children to learn from the Pakistani culture and Pakistani children the opportunity to see that the Afghan refugee community are not so different from themselves.

$$
\begin{aligned}
& \text { 'Boys and girls who have been able to be educated } \\
& \text { here in Pakistan have returned to Afghanistan } \\
& \text { and they are doing great work. Afghanistan } \\
& \text { desperately needs human resources. If you invest } \\
& \text { in educating children here in the refugee villages } \\
& \text { these children will be able to grow up and play } \\
& \text { a role in Afghanistan's future. Ifyou don't, we will } \\
& \text { never be able to put our country back on track'. } \\
& \text { Kashmir Khan, youth activist and } \\
& \text { Afghan refugee from Kot Chandana } \\
& \text { refugee village, now working in Kabul. }
\end{aligned}
$$

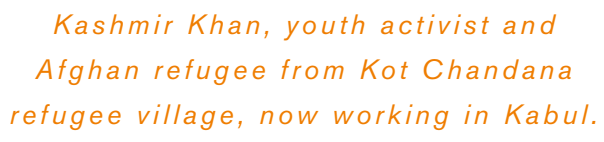

The Afghan community also identifies access to the full primary and secondary cycle of education as being vital to protecting young Afghans who might otherwise be vulnerable to exploitation, allowing them to work towards durable objectives of peace and repatriation. 


\section{MS AQEELA ASIFI, PIONEER IN}

\section{EDUCATING AFGHAN REFUGEE GIRLS}

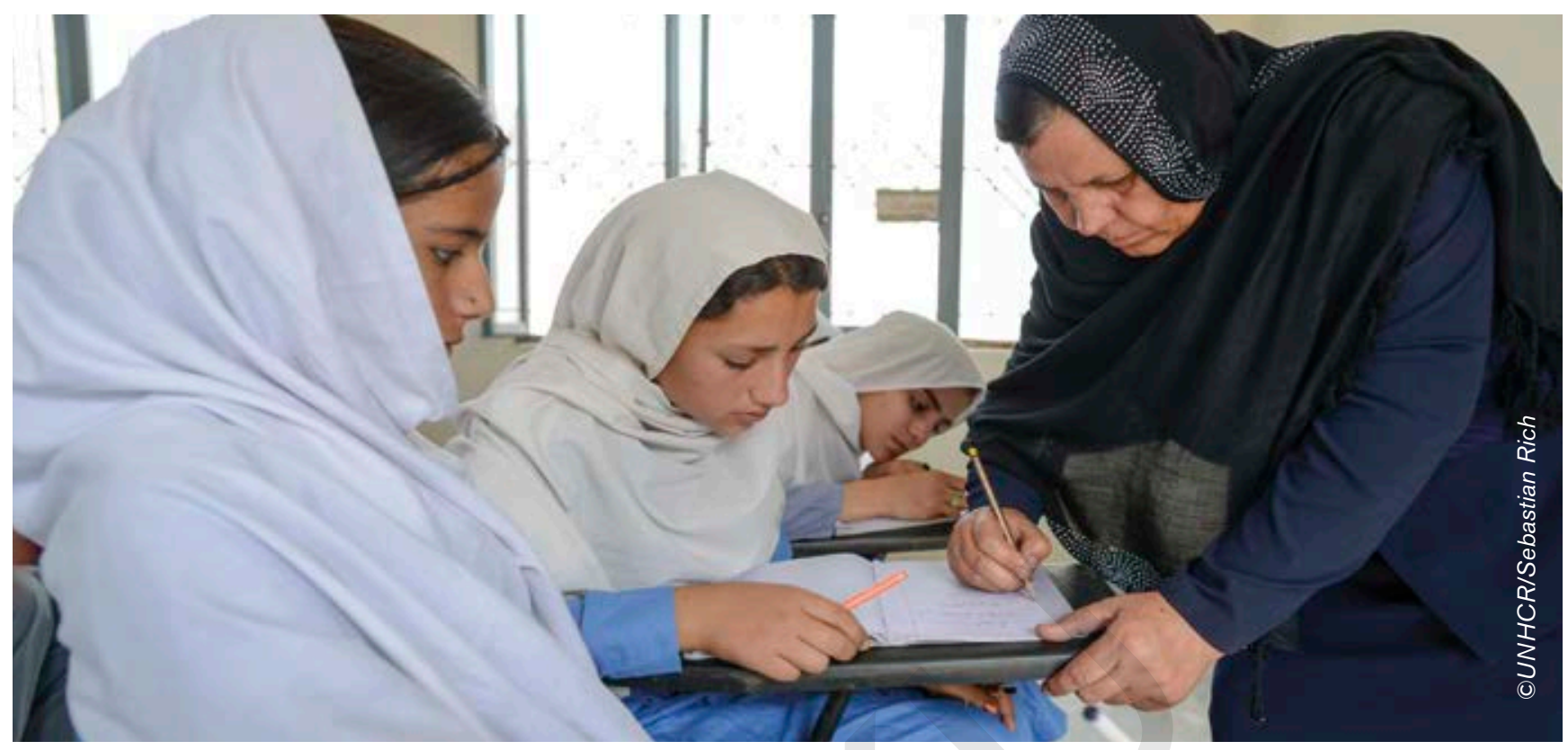

Aqeela Asifi is the 2015 winner of UNHCR's Nansen Refugee Award, recognised for her tireless efforts to provide education to hundreds of refugee girls.

A refugee herself, she fled Kabul, Afghanistan with her family in 1992 during the Mujahedeen siege and found refuge in Kot Chandana refugee village in the Punjab province of Pakistan.

As a former teacher Asifi was struck by the lack of schooling for girls - a consequence of the conservative culture in the refugee village - and was determined to teach them.

Winning the backing of the village elders, she bravely went door-to-door to convince reluctant parents to let her tutor their children. She began with just a handful of pupils in a makeshift school under a tent, writing out worksheets for the students by hand.

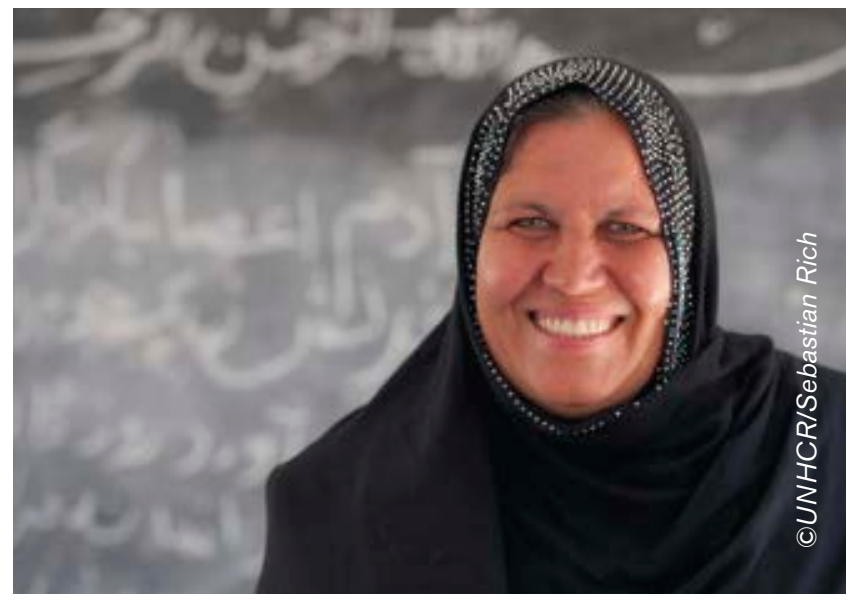

Over the next two years her tiny school blossomed and her accomplishments led to much-needed funding from the Pakistani government. This allowed Asifi to expand the school to six tents and include local Pakistani girls too.

Now, 23 years after she arrived, her tent-school is a permanent building, and has transformed the lives of more than 1,000 girl students who have reached eighth grade and received a nationally-endorsed certificate. Her teaching legacy has even had a cross-border impact with two of her former students taking up the profession in Kabul.

Asifi is a true symbol of triumph over adversity. With her quiet patience and determination she has changed the lives of hundreds of young refugees, offering them a pathway out of poverty, and a chance to build themselves a future. When asked about winning the Nansen Refugee award Asifi says the recognition is a shared one:

"The Award is for every girl who received an education from this school, and whose lives have been changed with this school. My reward is seeing a student learning to read and write.

So each day is a reward day." 
Addressing the shortage of trained teachers is also a priority, particularly female teachers, helping to reduce sociocultural barriers around the lack of female teachers and increase girls' chances of attending school. Since the beginning of 2015, UNHCR, through RAHA, has funded 200 teachers to attend a two-year mandatory teacher training diploma course. Most of these teachers have been women, initiating progress in addressing a significant barrier that negatively impacts both Pakistani and Afghan girls' education.

\section{Community and home-based interventions for girls}

In order to tackle some of the geographic, economic and sociocultural issues that restrict many Afghan girls' access to education, community and home-based programmes have been implemented in areas where need is particularly acute. Since the late nineties, UNHCR has provided home-based schooling options for girls in the southwestern Balochistan province, which borders with the Federally Administered Tribal Areas (FATA). More recently, under the Educate A Child programme, implemented since 2012, a dozen home-based primary level schools are supported in the province for Afghan refugee girls aged eight and above, who have previously missed the opportunity to access education. Twelve female teachers are drawn from the Afghan refugee community and the school operates in the teachers' own homes. A total of $\mathbf{3} 36$ girls are benefiting from these schools, which also have a community mobilisation component, using school management mechanisms to identify out-of-school girls and encourage more parents to allow their daughters to attend.

Community-based primary and secondary schools, such as that set up and run by Aqeela Asifi are also proving innovative and effective solutions to the barriers experienced by Afghan girls. Born from and sustained by the passionate dedication of individuals like Asifi, community girls and boys schools are testament to the capacity of educated Afghans to identify and take forward their own solutions for a better future, providing the opportunity for Afghan youth to realise their full potential. Through community-based primary and secondary schools, Afghan girls and boys who would otherwise be excluded from education through poverty, distance or sociocultural barriers are being given the chance to learn, acquire vital skills and make progress towards their sustainable return to Afghanistan. Whilst these initiatives are community-led and in many cases community funded, vital support has and can be given, through teacher training, books and curriculum resources, certification support and capacity development for learning environments, ensuring they are gender-sensitive and fit for purpose.

\section{The Solution Strategy for Afghan Refugee (SSAR)}

The Solutions Strategy for Afghan Refugees (SSAR) is the result of a unique and unprecedented quadripartite consultative process between the Islamic Republics of Afghanistan, Iran and Pakistan and UNHCR, initiated in 2011 to identify and implement lasting solutions for Afghan refugees in the region.

Designed as a regional multi-year initiative, the Strategy offers a comprehensive and integrated framework for joint action aimed at facilitating voluntary return and sustainable reintegration, while at the same time providing assistance to host countries.

The cross-cutting element of the SSAR is empowerment of Afghan refugees, particularly youth, through inter-linked interventions in the areas of education, skills enhancement and livelihoods support, so as to prepare them for voluntary repatriation by building their human capital and expanding livelihood opportunities in Afghanistan, while supporting self-reliance and thereby allowing for greater contribution to host country economies pending return.

Three Pillars of the Solutions Strategy:

- Creating conditions conducive to voluntary repatriation through community-based investments in areas of high return

- Building Afghan refugee capital based on livelihood opportunities in Afghanistan to enable sustainable reintegration

- Preserving protection space in host countries, including enhanced support for refugee hosting communities and resettlement in third countries

Since its endorsement by the international community in 2012, the Solutions Strategy has served as an enabling multilateral platform for consensus-building, strengthening of existing partnerships and engagement of new actors. Country portfolios of projects have been developed to support the implementation of SSAR at national levels, including crossborder initiatives aimed at continued education, skills development and linkages between labour markets in Afghanistan and host countries (21). 


\section{Skills and vocational training for Afghan youth}

Improved livelihood opportunities are key to breaking the cycle of poverty within which generations of Afghan refugees are stuck. For those refugees who missed out on education altogether or were obliged to drop out, skills and vocational training often provides the missing link, through which individuals, families and thus communities can be sustainably lifted out of poverty. Under the regional Solutions Strategy for Afghan Refugees (SSAR), skills and vocational training is a key solution to allow Afghan refugees the opportunity to sustainably support themselves and their families within their host communities, as well as

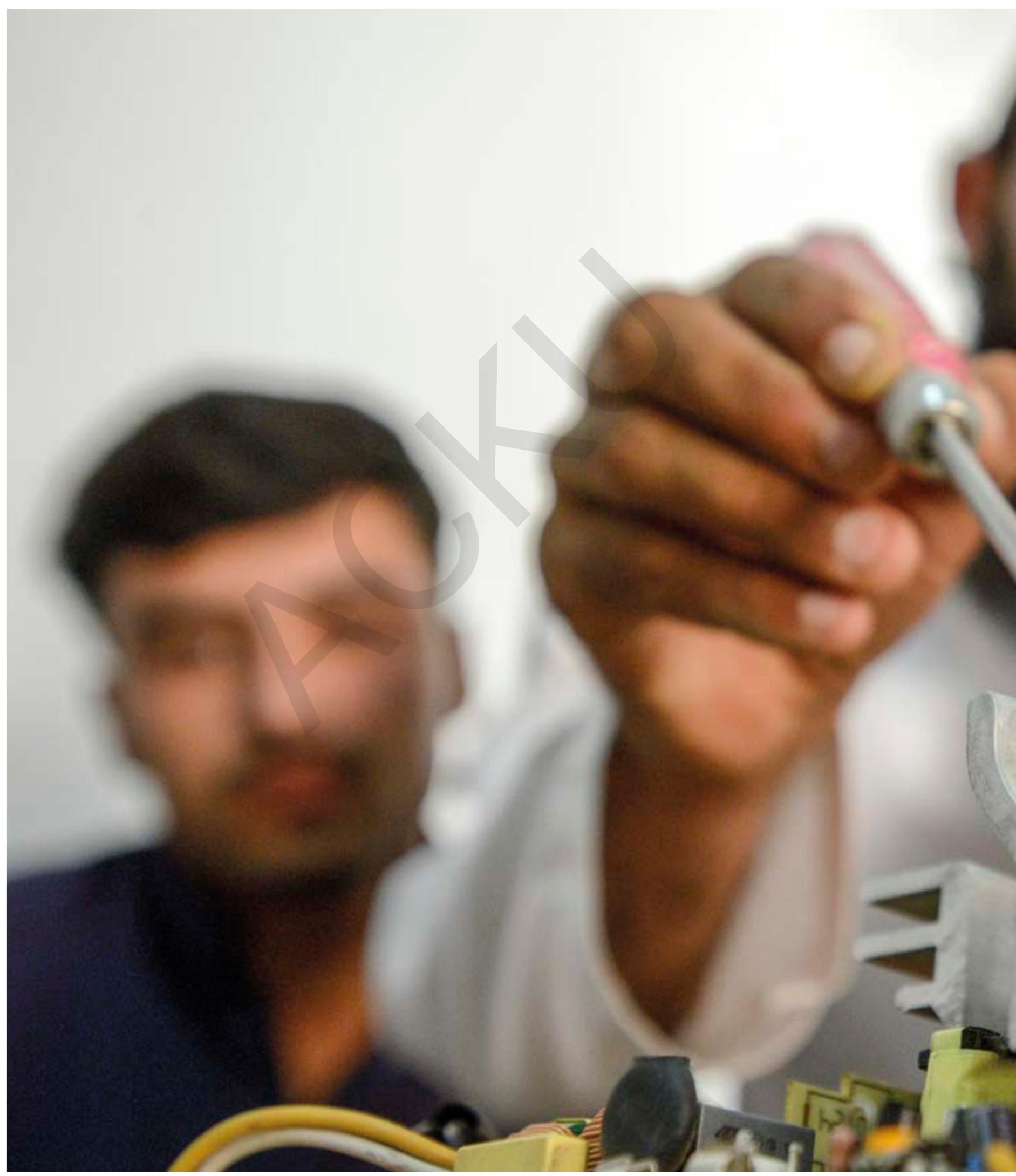


upon return to Afghanistan. UNHCR, other UN agencies, national and international NGOs, together with the Pakistani Government, are working to allow Afghan refugees access to vital training in vocational skills - including tailoring, computers, masonry, plumbing, mobile phone repair and auto mechanics. These interventions have proven particularly successful for women and female youth, increasing their mobility and the opportunity to contribute financially to their families. Training also allows the Afghan community to better contribute to their host community, through the informal labour market. Increasing access to relevant and appropriate skills, this work significantly improves the prospects of Afghan refugees being able to sustainably return to Afghanistan. 


\section{SUMMARY}

In 1980, nobody could have imagined that the complex conflict in Afghanistan would continue for three decades, resulting in the displacement of millions of Afghan people and leading to generations of Afghan children being born in exile. In education, early responses for the displaced were tailored to address a short-term crisis rather than the complex realities of protracted displacement. As the numbers of refugees increased and displacement wore on, the available education options became woefully inadequate, leading to limited and inconsistent access to primary and secondary education for Afghan refugees. At the same time, an international shortfall in funding for refugee education has made it increasingly challenging for host governments and development and humanitarian actors, such as UNHCR, to sufficiently ensure consistent access to primary and secondary education for all Afghan refugees.

Thirty-five years down the line, Afghan refugees are feeling the impact of the inability of successive generations to consistently access primary and secondary education or other learning options. The lack of consistent access to quality education has added to the burden on host countries as well as undermining development at home in Afghanistan - leading to a lack of teachers and a limited professional workforce. It has particularly impacted women and girls, perpetuating socio-cultural restrictions and many of the vulnerabilities which accompany lack of education.

However, whether through the generous support of host countries allowing Afghans to enrol in public education systems, NGO and UNHCR-supported schools and training centres, or as a result of inspiring community driven initiatives, those who do access learning - particularly girls - provide shining examples of its profound benefits. Educated Afghan refugees provide hope for a better future for Afghanistan, aid progress towards durable solutions, such as repatriation, for their communities, increase education opportunities for future generations and contribute to sustainably lifting families and communities out of poverty.

This month, September 2015, the UN General Assembly will adopt the Sustainable Development Goals (SDGs), which take forward the progress of the Millennium Development Goals to address the challenges and gaps that still remain. The SDGs provide a unique opportunity to ensure that refugee education, particularly for those in protracted displacement, is given the international focus, effort and funding support that it so desperately needs. Under the targets related to Sustainable Development Goal 4 - to ensure inclusive and equitable quality education and promote lifelong learning opportunities for all - there is finally recognition of the rights and needs of migrants and refugee children and youth. This opportunity for renewed focus must be seized, to ensure refugee children are given the same rights to a brighter future as any other child.

October 2015 will also see the international community, host governments, NGOs, the UN and other stakeholders come together at a ministerial level-meeting on the Afghan refugee situation, to discuss challenges and solutions as well as make commitments in support of Afghanistan, Pakistan and Iran. This platform is a crucial moment in which to recognize and support youth empowerment through increased access to education and training, as an integral part of realizing lasting solutions for Afghan refugees, within the framework of the Solutions Strategy for Afghan Refugees (SSAR).

There is still a long way to go to ensure that all Afghan refugee children and youth have access to certified, quality primary and secondary education and training opportunities in safe learning environments. However, with renewed focus and further strategic support for innovative solutions that are responsive to need - including the grassroots work of inspiring community educators like Aqeela Asifi - education and training opportunities for Afghan children and youth will significantly improve. Through investing in quality education, Afghan refugees will be given the tools to sustainably rebuild their lives and communities, providing renewed hope and opportunity to finally return home.

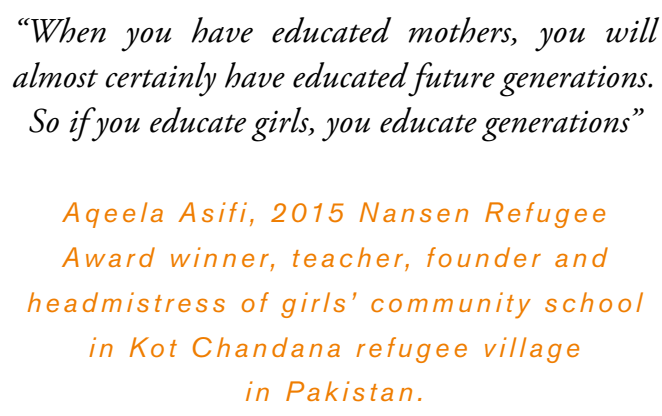
almost certainly have educated future generations. So if you educate girls, you educate generations" 


\section{REFERENCES}

\section{UNESCO}

2. World Bank, 2011

3. UNHCR Global Trends Report, 2014

4. UNHCR Note on Afghan Refugee Education in Pakistan, 2014

5. UNHCR Pakistan Education Strategy 2015-2017

6. Alif Ailaan, 25 Broken Promises: The Crisis of Pakistan's Out of School Children, 2014 (http://www.alifailaan.pk/broken_promises)

7. UNESCO National Literacy Programme figures (http://www.unesco.org/uil/litbase/

?menu=14\&programme=66)

8. World Bank Data, 2012, (http://data.worldbank.org /indicator/SE.ADT.1524.LT.ZS/countries/

IR?display=graph)

9. Council on Foreign Relations, Women and Girls in Afghanistan Transition, Working Paper, June 2014

10. UNESCO Education for All Global Monitoring Report 2011

11. UNHCR Education Unit, Geneva, 2015

12. Educate A Child Initiative, Good Practices for Gender Equality in education: Increasing access to education for girls through home-based schooling.
13. Education for All 2000-2015: achievements and challenges background paper, 2015 (http://www.ungei.org/resources/files/ Addressing_early_marriage_efa.pdf

14. World Bank, Voice and Agency: Empowering Women and Girls for Shared Prosperity report, 2014 (http://www.worldbank.org/content/dam/ Worldbank/document/Gender/Voice_and_agency _LOWRES.pdf)

15. UNESCO Education for All Global Monitoring Report 2011

16. UNHCR Population Profiling Verification and Response Survey, 2011 (http://unhcrpk.org/wpcontent/uploads/2012/11/PPVR-Report.pdf)

17. UNICEF Child Protection from violence, exploitation and abuse (http://www.unicef.org/protection/57929 _child_labour.html)

18. World Bank Girls Education Brief, 2014 (http://www.worldbank.org/en/topic/education/ brief/girls-education)

19. UNESCO Education Transforms Lives report, 2013 (http://unesdoc.unesco.org/images/0022/002231/ 223115E.pdf)

20. UNICEF Progress for Children Report Card, 2005

21. More information on SSAR and relevant documentation is available at http://www.unhcr.org/pages/4f9016576.htm/ 
